\title{
Interactions between the Interpretation of Article 10 ECHR and the EU Directive on the Protection of Whistleblowers
}

\author{
Marcin Górski ${ }^{1}$ \\ https://doi.org/10.18778/8220-639-5.02
}

\section{Introduction}

Directive 2019/1937 provides for measures concerning whistleblowers reporting breaches of EU law which protect them when they report internally within a given organization (Article 7) or externally (Article 10) or made a public disclosure (Article 15).

Pursuant to Article 15 of the Directive 2019/1937, a person who makes a public disclosure shall qualify for protection under this Directive if any of the following conditions is fulfilled:

(a) the person first reported internally and externally, or directly externally in accordance with Chapters II and III, but no appropriate action was taken in response to the report within the timeframe referred to in point (f) of Article 9(1) or point (d) of Article 11(2); or

(b) the person has reasonable grounds to believe that:

(i) the breach may constitute an imminent or manifest danger to the public interest, such as where there is an emergency situation or a risk of irreversible damage; or

(ii) in the case of external reporting, there is a risk of retaliation or there is a low prospect of the breach being effectively addressed, due to the particular circumstances of the case, such as those where evidence may be concealed or destroyed or where an authority may be in collusion with the perpetrator of the breach or involved in the breach.

1 Dr hab., Professor at the University of Lodz.

2 Directive (EU) 2019/1937 of the European Parliament and of the Council of 23 October 2019 on the protection of persons who report breaches of Union law, OJ L 305, 26.11.2019, pp. 17-56. 
Recital 31 of the Directive reads that "Persons who report information about threats or harm to the public interest obtained in the context of their work-related activities make use of their right to freedom of expression. The right to freedom of expression and information, enshrined in Article 11 of the Charter and in Article 10 of the Convention for the Protection of Human Rights and Fundamental Freedoms, encompasses the right to receive and impart information as well as the freedom and pluralism of the media. Accordingly, this Directive draws upon the case law of the European Court of Human Rights (ECHR) on the right to freedom of expression, and the principles developed on this basis by the Council of Europe in its Recommendation on the Protection of Whistleblowers adopted by its Committee of Ministers on 30 April 2014".

Obviously, it is not the very reference to Article 10 ECHR in the recitals of the Directive, but above all Article 6(1) TEU read jointly with Article 52(3) ChFR that result in that the standard of safeguarding the whistleblowers' freedom of expression provided for in the Directive must be construed as at least equivalent to that stemming from Article 10 ECHR. The aim of the present chapter is to establish whether the Directive allows for observing the Convention standard, or whether it provides for stronger protection reaching beyond the standard of the Convention. One should underline at the outset that the topical problem has been already discussed by legal scholars. ${ }^{3}$

\section{The standard of whistleblower protection under Article 10 ECHR}

The interpretation of Article 10 ECHR in the context of the protection of whistleblowers reaches back to the Moldovan case Guja. Since the delivery of that judgment in 2008, the Strasbourg standard has been consolidated and somewhat universalised. ${ }^{4}$ The present subchapter presents this evolution.

3 See e.g. D. Kafteranis and R. Brockhaus, Time to reconsider Strasbourg's whistleblower case law, https://europeanlawblog.eu/2020/09/21/time-to-reconsider-strasbourgs-whistleblower-caselaw/, accessed 01/09/2021, and V. Abazi and F. Kusari, Comparing the Proposed EU Directive on Protection of Whistleblowers with the Principles of the European Court of Human Rights, https:// strasbourgobservers.com/2018/10/22/comparing-the-proposed-eu-directive-on-protectionof-whistleblowers-with-the-principles-of-the-european-court-of-human-rights/, accessed 01/09/2021.

4 In the Polish legal scholarship, the evolution of the ECtHR case-law on whistleblowers has been presented by A. Ploszka - see Ochrona demaskatorów (whistleblowers) w orzecznictwie ETPCZ (Protection of whistleblowers in the case-law of the ECtHR), EPS 2014, No. 4, pp. 12-18, and M. Krzyżanowska-Mierzewska and A. Rutkowska - see Zagadnienia prawne zwiqzzane z ochronq whistleblowerów w warunkach zatrudnienia w ujęciu orzecznictwa ETPCZ (Legal issues relating to the protection of whistleblowers in the context of employment, as interpreted by the ECtHR), PS 2015, No. 4, pp. 106-122. Also, more generally on the status quo under international and 


\subsection{The emergence of the Convention standard of protecting whistleblowers. Guja v. Moldova}

In Guja v. Moldova, ${ }^{5}$ the applicant alleged a breach of Article 10 ECHR consisting in his dismissal from the Prosecutor General's Office for divulging two documents which he viewed as disclosing rather grave interference in pending criminal proceedings by a high-ranking politician. None of these documents were classified as confidential. After they were sent to a newspaper, an article was published criticising the political pressure in public prosecution. The applicant was nevertheless dismissed from his office. The reasons for his dismissal were the confidentiality of both documents and the applicant's failure to consult their disclosure with the heads of some departments at the Prosecutor General's Office. The Court held that the interference was permitted by law and served the legitimate aim of protecting the authority of the administration of justice as well as preventing crimes and protecting the reputation of others. Therefore, the Court had to consider whether the interference was "necessary in a democratic society".

The Court held that although "Article 10 applies also to the workplace, and [...] civil servants, such as the applicant, enjoy the right to freedom of expression", nonetheless "employees have a duty of loyalty, reserve and discretion to their employer. This is particularly so in the case of civil servants since the very nature of civil service requires that a civil servant is bound by a duty of loyalty and discretion". Nevertheless, the Court expressed the view that "a civil servant, in the course of his work, may become aware of in-house information, including secret information, whose divulgation or publication corresponds to a strong public interest" and "the signalling by a civil servant or an employee in the public sector of illegal conduct or wrongdoing in the workplace should, in certain circumstances, enjoy protection. This may be called for where the employee or civil servant concerned is the only person, or part of a small category of persons, aware of what is happening at work and is thus best placed to act in the public interest by alerting the employer or the public at large". The Court added that "in the light of the duty of discretion [...], disclosure should be made in the first place to the person's superior or other competent authority or body. It is only where this is clearly impracticable that the information could, as a last resort, be disclosed to the public".

Further, the Court developed a six-element test applicable in the assessment of interferences regarding the whistleblowers' freedom of expression:

domestic (Polish) law on whistleblowers, including the case-law of the ECtHR: H. Szewczyk, Ochrona prawna pracowników-sygnalistów (uwagi de lege lata i de lege ferenda) [Legal protection of whistleblowers (remarks de lege lata and de lege ferenda)], PS 2020, No. 1, pp. 7-22.

5 Judgment of ECtHR (GC) of 12 February 2008, Guja v. Moldova, appl. No. 14227/04. See the comments on that judgment in K. Badźmirowska-Mastowska, The Protection of Whistle-blowers within the Latest Initiatives of the Council of Europe, Adam Mickiewicz University Law Review 2019, vol. 9, pp. 151-165. 
First, it must be established whether the applicant had any effective alternative channels to use in order to prevent or combat breaches of law which he intended to disclose.

Second, while reviewing the proportionality of interference regarding the freedom of expression of a civil servant in such a case, regard must be had to a number of other factors, including, in the first place, to the public interest involved in the disclosed information, because "the interest which the public may have in particular information can sometimes be so strong as to override even a legally imposed duty of confidence".

Third, the authenticity of the disclosed information is of relevance - any person deciding to disclose such information must "carefully verify, to the extent permitted by the circumstances, that it is accurate and reliable".

Fourth, one "must weigh the damage, if any, suffered by the public authority as a result of the disclosure in question and assess whether such damage outweighed the interest of the public in having the information revealed" (since "the subject matter of the disclosure and the nature of the administrative authority concerned may be relevant").

Fifth, the "motive behind the actions of the reporting employee is another determinant factor in deciding whether a particular disclosure should be protected or not. For instance an act motivated by a personal grievance or a personal antagonism or the expectation of personal advantage, including pecuniary gain, would not justify a particularly strong level of protection [...]. It is important to establish that, in making the disclosure, the individual acted in good faith and in the belief that the information was true, that it was in the public interest to disclose it and that no other, more discreet, means of remedying the wrongdoing was available to him or her".

Sixth, the review of the challenged interference must concern also the severity (proportionality) of the sanction applied in respect of the whistleblower.

The Court held against these criterions in Guja that the applicant had not had at his disposal another, alternative measure likely to counteract the irregularities which he reported, that he had acted in order to protect a legitimate public interest, that he had divulged (which was not disputed in the case) authentic information, that the interests of preventing political interferences with the functioning of public prosecution overweighed the possible detriment to the general public's confidence in the administration of justice, that he had acted in good faith and that the sanction applied in respect of him - termination of the work contract - had been particularly severe. In view of these circumstances, the Court found a violation of Article 10 ECHR.

A structurally similar case was Bucur and Toma v. Romania ${ }^{6}$ concerning secret service officers convicted for publicly disclosing, during a press conference, state secrets concerning illegal surveillance regarding journalists, politicians and businesspersons.

6 Judgment of ECtHR of 8 January 2013, Bucur and Toma v. Romania, appl. No. 40238/02. 


\subsection{Generalization of the Guja standard. Heinisch v. Germany}

The Guja ruling concerned explicitly a public servant reporting irregularities, and the Court in its reasoning on several occasions underlined the particular circumstances regarding the employment of a public officer. However, the Court generalized the application of the Guja doctrine in the Heinisch v. Germany ${ }^{7}$ ruling, which concerned a geriatric nurse employed in a state-owned company providing medical services. The applicant was fired without notice after she informed the prosecution of a suspected crime allegedly committed by her employer, while accusing the company, among others, of "serious shortcomings in the daily care provided there, caused by a shortage of staff".

The Court noted that (point 71) "the information disclosed by the applicant was undeniably of public interest. In societies with an ever growing part of their elderly population being subject to institutional care, and taking into account the particular vulnerability of the patients concerned, who often may not be in a position to draw attention to shortcomings in the provision of care on their own initiative, the dissemination of information about the quality or deficiencies of such care is of vital importance with a view to preventing abuse. This is even more evident when institutional care is provided by a State-owned company, where the confidence of the public in an adequate provision of vital care services by the State is at stake". As for the authenticity of the disclosed information, the Court remarked that the applicant had previously reported irregularities to her principals and that "allegations made by the applicant were [...] not devoid of factual background and there is nothing to establish that she had knowingly or frivolously reported incorrect information". Like in Guja, also in this case the Court found a violation of Article 10 ECHR.

Structurally similar cases were Marchenko v. Ukraine, ${ }^{8}$ in which the applicant, both a teacher and a trade union activist, was sentenced for defamation of the school's headmaster, whom they had accused of financial irregularities, and Matúzv. Hungary, ${ }^{9}$ which involved a journalist of a public television dismissed for publicly disclosing allegations on censorship practices entertained by the employer. An interesting and at the same time again structurally similar case was Rubins v. Latvia, ${ }^{10}$ were the Court found a violation of Article 10 ECHR on account of terminating the work contract with an academic teacher who criticized, in an internal exchange of correspondence addressed to the president of the university, certain organizational changes introduced at the applicant's faculty. One should probably mark this judgment as a particularly protective for whistleblowers if one takes into consideration that the letter addressed to the university's president could hardly be treated as

7 Judgment of ECtHR of 21 July 2011, Heinisch v. Germany, appl. No. 28274/08.

8 Judgment of ECtHR of 19 February 2011, Marchenko v. Ukraine, appl. No. 4063/04.

9 Judgment of ECtHR of 21 October 2014, Matúz v. Hungary, appl. No. 73571/10.

10 Judgment of ECtHR of 13 January 2015, Rubins v. Latvia, appl. No. 79040/12. 
anything else than a form of a rather poorly camouflaged blackmail. ${ }^{11}$ The Court nevertheless held that the applicant had defended the public interest and had not been inspired by any personal motives, that he had not impaired the reputation of the interested persons (or, at least, it had not been convincingly established by national authorities), and that the sanction imposed on him had been significantly severe.

Finally, one should also mention the Aurelian Oprea v. Romania ${ }^{12}$ case, where the Court held that there had been a violation of Article 10 ECHR, yet at the same time that - contrary to the observations made by the applicant, who had publicly accused the academic community of corruption and scientific dishonesties - the case was not about whistleblowing.

\subsection{Instances of refusal to find breaches of Article 10 ECHR in respect of applicants labelling themselves whistleblowers}

We can also find examples of the Court's case-law showing that the Court sometimes refuses to grant protection under Article 10 ECHR to (applicants alleging to be) whistleblowers.

In Soares v. Portugal, ${ }^{13}$ the Court found no violation of Article 10 ECHR. The applicant, an officer of Guardia Nacional Republicana, had been sentenced to a fine of EUR 720 and a disciplinary sanction of suspension in duties for six days (conditionally suspended as a probative measure) for insulting his principal through accusing him, in a letter addressed to the internal auditing services of the Guardia, of a certain embezzlement. The Court emphasised that the applicant had been aware from the very beginning that his allegations were based on rumours but he had taken no effort to verify them. Furthermore, as the Court held, the applicant had not made use of any alternative channels of communicating the alleged irregularities and he failed to explain it. What the Court took into account as well was a relatively low level of severity of the sanction applied in respect of the applicant.

The Court found no violation either in the Gawlik v. Liechtenstein ${ }^{14}$ case, where the applicant, a doctor of medicine, had been dismissed without notice for notifying public prosecution of a suspicion of the crime of illegal euthanasia, yet without having previously verified those allegations in any way except for simply noting that four patients had died after being given doses of morphine. The Court highlighted that national courts had applied the Guja test and that their assessment did not raise the concerns of the ECtHR.

11 Let us quote a passage from the applicant's piece of epistolographic art: "If we are unable to reach agreement by signing a settlement agreement I will make all my current information public in the form of an open letter so that the members of the constituent assembly of the University also have at least one day before the meeting to think about their vote".

12 Judgment of ECtHR of 19 January 2016, Aurelian Oprea v. Romania, appl. No. 12138/08.

13 Judgment of ECtHR of 21 June 2016, Soares v. Portugal, appl. No. 79972/12.

14 Judgment of ECtHR of 16 February 2021, Gawlik v. Liechtenstein, appl. No. 23922/19. 
Similarly, in Medžlis Islamske zajednice Brčko and others v. Bosnia and Herzego$v_{i n a^{15}}$ (one should note that the judgment was adopted with a majority of eleven votes in favour against six votes against, with three dissenting opinions criticizing the majority's findings), the Court held that there had been no violation of Article 10 ECHR on account of applying criminal sanctions for defamation committed by the applicants in respect of a candidate for the post of the head of a local radio station. They had accused the candidate of lacking professional and moral qualifications for the position she was applying for. The defamation had occurred in a letter addressed to international authorities supervising Brčko, which had been also published in the media in a form of an open letter. The defamation had been committed pending the recruitment procedures for the position of the head of the local radio broadcaster. The Court found it decisive that the applicant had failed to verify their allegations prior to announcing them publicly.

\section{The mechanism of Article 15 of the EU Directive 2019/1937}

The instrument of Article 15 of the Directive 2019/1937, being the ultima ratio of whistleblowing action, ${ }^{16}$ permits making a public disclosure where:

a) the whistleblower made an internal report (Article 7 of the Directive) or an external one (Article 10) but no appropriate action was taken in response to the report within the time limit of 3 months (in case of internal reporting) or 6 months (in case of external reporting), or,

b) the whistleblower has reasonable grounds to believe that the breach may constitute an imminent or manifest danger to the public interest, or in the case of external reporting, there is a risk of retaliation or there is a low prospect of the breach being effectively addressed, due to the particular circumstances of the case.

One ought to remark at the outset that some semantic divergences appear between the Polish and the French and the English official versions of the Directive 2019/1937. Firstly, the term "reasonable" (raisonnables) employed in the initial sentence of

15 Judgment of ECtHR [GC] of 27 June 2017, Medžlis Islamske zajednice Brčko and others v. Bosnia and Herzegovina, appl. No. 17224/11.

16 See - accurately - Ł. Łaguna, Ochrona interesu publicznego a dyferencjacja roli sygnalisty (Protection of the public interest and the differentiation of the role of the whistleblower), [in:] B. Baran, M. Ożóg (eds.), Ochrona sygnalistów. Regulacje dotyczq̨ce osób zgłaszających nieprawidłowości (Whistleblower protection. Regulations concerning persons reporting irregularities), Wolters Kluwer, Warsaw 2021, in subchapter 3 of the chapter Status prawny sygnalisty na gruncie dyrektywy 2019/1937. 
Article 15(1)(b) of the Directive has been translated to Polish as uzasadnione (legitimate), which - in Polish - refers to a situation where one is in possession of evidence or at least has legitimate arguments that an irregularity occurred, whereas the term "reasonable" (raisonnables) employed in the compared language versions can be attributed, at least to a larger extent, to the subjective assessment of a whistleblower who presents an appraisal of circumstances in accordance with an abstract concept of a "reasonable person" while basing that appraisal on the sources available to him or her. The concept of a "reasonable person" is actually well known to the European scholarship and case-law. ${ }^{17}$ Secondly, the Polish word sqdzić (to appraise, to assess) is employed in the same provision as the equivalent to "to believe" in the English version and croire in the French official version of the Directive. Here again, one can trace a certain shift of accents at the semantic level since "appraisal" requires stronger evidence than a "belief". Sadly, this type of translation errors is likely to adversely affect and contaminate both the future legislative transposition and the practical application of national provisions (implementation largo sensu). On the other hand, these semantic doubts perhaps fade away when viewed against the background of much more dramatic interpretational shortcomings, such as the one in Article 5(4) of the Directive. This provision reads in English that "internal reporting means the oral or written communication of information on breaches within a legal entity in the private or public sector" (and identically in French: "«signalement interne»: la communication orale ou écrite d'informations sur des violations au sein d'une entité juridique du secteur privé ou public"), whereas in the Polish version one can be surprised that the same passage is worded as follows: "zgłoszenie wewnętrzne oznacza ustne lub pisemne przekazanie informacji na temat naruszeń $w$ obrębie podmiotu prywatnego $w$ sektorze prywatnym lub publicznym" (literally: within a private entity in the private or public sector, au sein d'une entité privé du secteur privé ou public). Nonetheless, also the malfunctions in the Polish wording of Article 15 of the Directive represent a sufficient potential of "confusing the enemy", i.e. the whistleblower or the national authority responsible for affording him or her protection pursuant to the Directive.

\section{The compatibility of Article $\mathbf{1 5}$ of the Directive with the Guja standard}

One can make the following remarks when analysing the conformity of Article 15 of the Directive with the Strasbourg case-law.

Firstly, and most obviously, under the Directive, the motivation behind a public disclosure (and more generally - behind any whistleblower's action protected by

17 See e.g. H. Howells, Ch. Twigg-Flesner, T. Wilhelmsson (eds.), Rethinking EU Consumer Law, Routledge, London-New York, 2018, p. 7 - see in particular the case-law referred to in footnote 22. 
the Directive) is irrelevant. It has been explicitly clarified in recital 32 (in fine) of the Directive that "the motives of the reporting persons in reporting should be irrelevant in deciding whether they should receive protection" (Fr. les motifs amenant les auteurs de signalement à effectuer un signalement devraient être sans importance pour décider s'ils doivent recevoir une protection). This finding is sufficient to support the assumption that the Directive improves the standard of protection in this respect in comparison to that afforded by the Guja standard of interpretation of Article 10 ECHR, which is harmonious with the second sentence of Article 52(3) of the Charter of Fundamental Rights. The editorial and topical framework of this chapter does not allow for more than a brief mention of the problem of the interpretation of Article 52(3) ChFR in the context of cases where raising the level of protection (in the EU measure) of one of the rights or freedoms guaranteed simultaneously under the ECHR and the ChFR (here: freedom of expression) inevitably implies as a corollary that the intensity of protection of another right or freedom protected by both instruments is reduced (here, at least potentially: the right to peaceful enjoyment of possession protected by Article 1 of Protocol 1 to the ECHR or the reputation safeguarded by Article $8 \mathrm{ECHR}$ ). The issue noted here deserves a more in-depth conceptual analysis.

Secondly, uncertainties arise in respect of the delineation of circumstances justifying public disclosure defined in Article 15 of the Directive, if viewed from the perspective of the first element of the Guja standard. Let us rephrase that according to the first element of the test, the whistleblower's freedom of expression is protected (Article $10 \mathrm{ECHR}$ ) when he or she made a public disclosure in the absence of any other effective means of counteracting irregularities that he or she intended to disclose. At the same time, the Directive reads in Article 15 that the whistleblower can either report internally (or immediately externally) and then wait (somewhat in vain) until the applicable timeframes for reaction of the addressees of his/her reporting expire ineffectively, or divulge information publicly only where reasonable reasons exist to believe that there is an imminent hazard to public interest or that there is a risk of retaliatory measures or ineffectiveness of milder whistleblowing actions.

In other words, an immediate public disclosure is exclusively permissible (i.e. protected by Article 15 of the Directive) in cases of imminent or manifest danger to the public interest (let us call it, for the sake of this analysis, the "prerequisite of imminence") or where more discrete whistleblowing action implies the risk of retaliation or ineffectiveness (which we can jointly refer to as the "prerequisite of ineffectiveness", assuming that it includes likewise retaliatory revenge, as such retaliation results in reducing the effectiveness of whistleblowing because the latter is not intended to result in the whistleblower losing their job). At the same time, the first and fourth element of the Guja test, read jointly, appear to allow for the conclusion that the way in which the interest that the whistleblower intends to protect is endangered, i.e. whether that interest is threatened directly and manifestly or not, does not seem to have significance for the protection afforded by the Convention. What is relevant, however, is whether the whistleblower employed alternative channels 
of communication of his/her allegations (i.e. whether he/she made use of more discrete whistleblowing actions) and whether the balancing of interests potentially impaired by reporting or divulging and the interest protected by whistleblowing proved that the former were outweighed - as the significance of the endangered public interest can be so heavy that it results in absolving a whistleblower from employing internal ways of reporting. Hence, where the public interest in disclosure outweighs the possible detriment to the entity affected by such a disclosure, neither the aforementioned way of endangering the public interest nor the occurrence of the prerequisite of imminence (as defined above) should impact the scope of protection afforded by Article 10 ECHR.

Thirdly, certain minor doubt arises when one compares Article 15 of the Directive and the Guja test, namely in reference to the link between the "exculpating" prerequisite of public disclosure and the protection of the "public interest". Let us clarify the point. Obviously, said link as such is appropriate since the Directive - as reflected in its Article 2(1) read jointly with Article 5(1) - applies solely to reporting or disclosing irregularities allegedly breaching the Union law, which is why its function (clearly differently than under Article $10 \mathrm{ECHR}$ ) is to protect the financial interests of the EU and not the freedom of expression as such (which is the consequence of the treaty-basis of the Directive rooted in, among others, Article 325 TFEU concerning the combating of fraud and any other illegal activities affecting the financial interests of the Union). Yet on the other hand, the wording of Article 15(1)(b)(i) is likely to cause interpretative uncertainties in cases where the reported or disclosed irregularity occurs in a private-sector entity and not in a public one. In such a case, the perpetrator of the irregularity ultimately impairs the interest of the private entity in which he/she commits the irregularity. The financial interest of the EU would be protected by the very whistleblower's action and the private entity would be ultimately held responsible, with all the legal and financial consequences included. When construing the proviso of Article 15(1)(b) (i) of the Directive, one should be aware of the general function of the Directive and avoid interpretational shortcomings leading to the flawed conclusion that no public interest was endangered if a whistleblower reported or divulged irregularities in a private entity.

\section{Conclusions}

The scholarly analyses mentioned at the outset of this chapter ${ }^{18}$ present contradictory conclusions on the conformity of the Directive with the Guja standard

18 D. Kafteranis and R. Brockhaus, Time to reconsider..., op. cit., and V. Abazi and F. Kusari, Comparing the Proposed EU Directive..., op. cit., see footnote 2. 
(and its aftermath). The work of V. Abazi and F. Kusari ${ }^{19}$ criticized the proposed EU provisions on the gradation of permissible methods of communicating irregularities (internal reporting - external reporting - public disclosure). Their criticism encompasses the alleged inconformity of that gradation with the Guja standard of interpretation of Article 10 ECHR. The article of D. Kafteranis and R. Brockhaus, to the contrary, is rather apologetic to the Directive and advocates the necessity of reconsidering the Strasbourg standard of whistleblower protection, which, in these authors' view, should be incompatible with the Directive. While we will not address here the somewhat novel and striking postulate of these authors concerning the need to adapt the case-law of the ECtHR to the Directive (let us quote: "from a normative perspective, the Strasbourg Court should reconsider its case law and align it with the Directive to ensure the same level of protection under Art. $10 \mathrm{ECHR}$ in all CoE Member States"), as it perhaps provokes a more complex reconsideration from the normative perspective, one can state that generally, to the extent discussed in the present chapter, Article 15 of the Directive does not reveal major inconsistencies if compared to the Guja standard (and its aftermath).

Nevertheless, certain doubts can probably be raised regarding a clear tendency of the Union lawmakers to abstain from conditioning the intensity of protection afforded by the Directive upon the motivation of the whistleblower. On the other hand, however, the same position of the Union law can be defended as logical if one takes the primary EU law basis of the Directive into consideration. Unlike under Article 10 ECHR, the ratio of the EU norms on whistleblower protection is to protect not freedom of expression as such (which appears in a way a side-effect of the Directive) but the financial interests of the Union. Keeping that in mind, it is hard to identify reasons why a whistleblower should be less protected if he or she acted upon low motives such as e.g. the intention to enjoy personal revenge.

More serious and well-founded, although still not dismantling the generally positive perception of Article 15 of the Directive, doubts arise when it comes to the apparent interpretational tension, presented above, between the Guja standard and Article 15(1)(b)(i) of the Directive providing for the conditioning of the immediate public disclosure upon the type (way) of danger posed by the reported or disclosed irregularity to the public interest for the sake of which a whistleblower acts. It would seem more plausible and compatible with the Guja test if the provision of the Directive, instead of the way in which the public interest is endangered, referred to balancing the significance of the public interest which the irregularity impedes of endangers against the possible impairment to the legally protected interests affected by whistleblowing.

19 One should, however, mention, for the sake of accurateness, that V. Abazi and F. Kusari discussed in their work, cited above, the European Commission's proposal of the Directive presented in 2018 [see EUR-Lex - 52018PC0218 - EN - EUR-Lex (europa.eu)], which was quite significantly different from the ultimately adopted text of the Directive, especially in respect of the conditions applicable to public disclosure. 


\section{Abstract}

This chapter presents the evolution of the Strasbourg case-law concerning the protection of whistleblowers, starting from the 2008 Guja v. Moldova judgment, and confronts the EU Directive's provisions on public disclosure with the ECtHR's relevant standard of interpretation of Article 10 of the Convention (the Guja's six-element test). The work concludes that there exist certain divergencies between the Convention standard and Article 15 of the Directive and that somewhat confusing wording of the latter provision is likely to cause future interpretative malfunctions if one employs only grammatic interpretation of that provision while forgetting about the general function and scheme of the Directive.

\section{Bibliography}

Abazi V., Kusari F., Comparing the Proposed EU Directive on Protection of Whistleblowers with the Principles of the European Court of Human Rights, https://strasbourgobservers. com/2018/10/22/comparing-the-proposed-eu-directive-on-protection-of-whistleblowers-with-the-principles-of-the-european-court-of-human-rights/, accessed 01/09/2021.

Badźmirowska-Masłowska K., The Protection of Whistle-blowers within the Latest Initiatives of the Council of Europe, Adam Mickiewicz University Law Review 2019, Vol. 9, pp. 151-165.

Howells H., Twigg-Flesner Ch., Wilhelmsson T. (eds.), Rethinking EU Consumer Law, Routledge, London-New York 2018.

Kafteranis D., Brockhaus R., Time to reconsider Strasbourg's whistleblower case law, https:// europeanlawblog.eu/2020/09/21/time-to-reconsider-strasbourgs-whistleblower-caselaw/, accessed 01.09.2021.

Krzyżanowska-Mierzewska M., Rutkowska A., Zagadnienia prawne związane z ochrona whistleblowerów $w$ warunkach zatrudnienia w ujęciu orzecznictwa ETPCz (Legal issues relating to the protection of whistleblowers in the context of employment, as interpreted by the ECtHR), PS 2015, No. 4, pp. 106-122.

Łaguna Ł., Ochrona interesu publicznego a dyferencjacja roli sygnalisty (Protection of the public interest and the differentiation of the role of the whistleblower), [in:] B. Baran, M. Ożóg (eds.), Ochrona sygnalistów. Regulacje dotyczące osób zgłaszających nieprawidłowości (Whistleblower protection. Regulations concerning persons reporting irregularities), Wolters Kluwer, Warsaw 2021.

Ploszka A., Ochrona demaskatorów (whistleblowers) w orzecznictwie ETPCz (Protection of whistleblowers in the case law of the ECtHR), EPS 2014.

Szewczyk H., Ochrona prawna pracowników-sygnalistów (uwagi de lege lata i de lege ferenda) [Legal protection of whistleblowers (remarks de lege lata and de lege ferenda)], PS 2020. 